\title{
Chapter 7 \\ Innovating Career Counseling \\ by Promoting Social Justice (Advocacy) \\ and Decent Work for All: Helping People \\ Make Social Contributions and Heal \\ Themselves
}

\author{
Everyone can rise above their circumstances and achieve \\ success if they are dedicated to and passionate about what they \\ do (Nelson Mandela)
}

\begin{abstract}
This chapter covers the emotional effect of changes in the world of work that have taken place globally over the past few decades on people. The discussion then moves to the need for and importance of career counseling as a means to help people interpret and deal with these changes. Also discussed is the idiosyncratic situation and needs of people in disadvantaged areas, as well as the importance of attending to their career counseling needs. A case study showing how career counseling can be postmodernized in a seriously disadvantaged environment is presented before the chapter is concluded.
\end{abstract}

\subsection{Orientation}

Since the current socioeconomic disruption is at its worst among the most disadvantaged and vulnerable populations (such as those in rural regions, informal settlements, and townships), I believe that innovation in career counseling should first and foremost target and be guided by the unique needs of these populations. The impact of occupational changes on disadvantaged people especially is devastating. In many previous publications, over the past two decades in particular, my colleagues and I (Maree, 2018, 2019a, 2019d) have elaborated on the horrendous influence of occupational changes on the career-lives of people in general but on disadvantaged people in particular. Workers often experience their work as lacking meaning and alien and subsequently struggle to come to terms with all the changes that enforce numerous work transitions on them (Maree, 2015). Deprived of the former safe occupational spaces (Winnicott, 1964) work used to provide for them, many workers have lost their jobs, struggle to find employment elsewhere, experience a sense of loss of control over key facets of their career-lives, and, eventually, their sense of meaning, purpose, and hope. In a sense, one can therefore argue that many people's biggest 
career counseling need today is no longer "vocational guidance", "career education", or even "career counseling" but rather "employability counseling" (Fugate \& Kinicki, 2008; Guilbert et al., 2016). Because career adaptability is a key prerequisite for employability, promoting such adaptability lies at the heart of helping people become employable.

Unemployment poses a far greater challenge in Global South countries, for instance in Africa, than in Global North countries. According to the International Labor Organization (ILO, 2019, p. 1): "In 2017, extreme working poverty remained widespread, with more than 300 million workers in emerging and developing countries having a per capita household income or consumption of less than US\$1.90 (PPP) [1.65 Euro] per day. Overall, progress in reducing working poverty is too slow to keep pace with the growing labor force in developing countries, where the number of people in extreme working poverty is expected to exceed 114 million in 2018, or 40 per cent of all employed people." In addition (ILO, 2019, p. 1), "the number of workers in vulnerable forms of employment (own-account workers and contributing family workers) is likely to increase in the years to come". Seemingly, there is very little chance of global poverty being eradicated, as specified in the United Nations Sustainable Development Goals (UN, 2019). One of my greatest concerns is that resources-related structural inequalities have an extremely adverse emotional influence on people, and the impact is most destructive on young people. We therefore need to focus on disadvantaged people and the promotion of social justice or advocacy in our efforts to innovate and renovate career counseling. Seen from this perspective, the link between career counseling and social justice (advocacy) is clear.

I have witnessed first-hand during many research projects and outplacement workshops the daunting hardships people living in these conditions have to endure. Hearing them express their sense of hopelessness, desperation, marginalization, and pain has touched me deeply. Worryingly, young people are increasingly venting their anger and frustration about their dire work situation. They are aware that most of them will not realize their dream of finding sustainable, decent work, irrespective of how hard they try or their level of training. Consequently, the future looks bleak, with little chance that spiraling unemployment will decline. This also means that crime and lawlessness (often resulting from the inability to find sustainable work) are likely to become even worse in the future.

In their desperate quest for some kind of work, disadvantaged people generally have no one to turn to for career counseling. Even when they do receive vocational guidance, the need to uncover their initial, deep-rooted (often subconscious) "pain" (driving motives) is not attended to. There is insufficient evidence of active self- and career construction (Maree, 2014a, 2014b; Savickas, 2011a, 2011b). This matter will be discussed next. 


\subsection{Importance of Attending to the Self- and Career Construction Counseling Needs of Disadvantaged People Especially}

Many children leave school without completing Grade 12 and/or achieving adequate marks in Grade 12, and also without having acquired important life skills or acquired some knowledge of business. Naidoo, Pretorius, and Nicholas (2017) state that career counseling is available to wealthy people in Global South countries such as South Africa but that indigent people simply cannot afford this often expensive service, which is deplorable as lack of such counseling exacerbates the already high unemployment among these people. The situation is made worse by the high level of student non-achievement' or 'poor achievement' in tertiary education (Maree, 2010a, 2019a). Making career counseling available to the millions of people who currently do not have access to this service can help reduce the high failure rate at tertiary institutions and thus contribute to economic growth and political stability. However, to achieve this aim, more is needed that mere expressions of intention, camaraderie, and empathy.

Below, I explain why eliciting subjective and objective career counseling information career counseling can best serve the needs of disadvantaged people.

\subsection{Significance of Eliciting Subjective and Objective Career Counseling Information from Disadvantaged People}

Previous research on people in disadvantaged contexts confirmed the importance of obtaining subjective, qualitative information on careers in addition to objective career-related information for such people (Maree, 2014a, 2014b, 2014c, 2014d, 2018) to help them choose appropriate careers and succeed in them. Not only do they generally display a serious lack of knowledge about careers (Brown, 2002), they are especially unsure about their career identities. In interventions in disadvantaged contexts, assessees' life stories should be elicited and interpreted circumspectly by professionals adequately acquainted with their contexts and skilled in administering career counseling in diverse contexts. Assessees should also be furnished with sufficient information about the world of work, and their scores in tests and at school should be interpreted dynamically. Even in cases where their perceptions appear unrealistic, it should be remembered that people are guided largely by their own perceptions of their skills and by their confidence in achieving success in a given field of study and its associated career.

The storied approach is fully compatible with Global South (such as African) contexts. In fact, this approach has been "practiced" across Africa for millennia. Stevens, Duncan, and Sonn (2010) contend that "black history ... has been passed on through the art of storytelling" (p. 18). Underlying this approach is the social 
constructionism paradigm, which advocates identity formation rather than personality traits, career adaptability rather than "maturity", the use of "stories" (narratives) along with "scores" (numbers), forward movement that culminates in action rather than passivity and mere intention, and becoming employable rather than merely looking for a job. Ultimately, the aim of this approach is to help people manage repeated career-related transitions in their work-lives and convert career counseling into an intervention (instead of an "assessment") that promotes reflexive, dialogical meaning co-construction by career counselors and their clients (Blustein, Palladino Schultheiss, \& Flum, 2004; Cardoso, Silva, Gonçalves, \& Duarte, 2014; McIlveen, Ford, \& Dun, 2005).

A case study showing how career counseling can be postmodernized in a seriously disadvantaged environment is presented below.

\subsection{Case Study: Life Design-Related Intervention in a Seriously Disadvantaged Context}

\subsubsection{My Experiences at the Good Work Foundation}

Below, I draw on my research-related experiences at the Good Work Foundation (GWF), which is under Kate, GWF's CEO, and Mo Groch's inspiring leadership. In a deep rural part of South Africa, the GWF is exemplifying the practical implementation of self- and career construction and life design theory. Of the adult learners, $90^{+} \%$ recently left school, are unemployed, and could not succeed in enrolling at a tertiary training institution. They lack the skills needed to become employable, and their possibilities of finding sustainable work are gloomy. With the support of key partners, the GWF presents fundamental literacy training and career education to school-aged and adult learners (visit http://www.goodworkfoundation.org for more information). In addition to running learning academies, the GWF offers English, mathematics, digital literacy, and life skills training courses for those learners still at school, while the GWF's career guidance academies offer digital literacy courses for adult learners.

A bridging year is offered to adult, unemployed school-leavers as a second chance to upskill themselves and enhance their chances of acceptance into fields of study they did not previously qualify for, thus improving their employability, career resilience, and career agility. After having acquired a sound English and digital literacy foundation, adult learners not only attend career academies (located at the digital learning centers) but also start serving the local economy. Specialized modules in wine, coffee, and front-of-house management can be completed or students can further their education by studying at the GWF's Information Communication Technology (ICT) Academy. Once they have successfully completed their training, they are employed locally, find employment elsewhere, or continue studying either online or at tertiary training institutions. 
What about the GWF approach is innovative? First, in a remote corner of Africa, they offer education and training that compares well with the best analogous training globally. Second, Kate and Mo Groch's realization of the importance of training their students in a way that promotes their career "adaptability" and "the proficiency to find employment" (employability) instead of merely helping them "find employment". Third, their emphasis on advancing their students' twin survival [thriving] skills of information communication technology (ICT) literacy and proficiency in English (the language of business globally). This insight and practice are consistent with Ross' (2016) view that becoming proficient in (a) English and (in certain instances) also in other foreign languages and in (b) the language of computers will help people communicate (connect, network) better-communication competency can arguably be regarded as the key skill that advances career adaptability and employability in today's occupational world. Fourth, their awareness of the importance of providing life- and career construction-based counseling for each student and offering training that is on a par with life design-based training anywhere else in the world.

Using the $C I P$ and the $M C M$, GWF colleagues could offer the latest qualitative (narrative, storied) career counseling to those learners who had completed their bridging year. This was a considerable achievement in a resource-scarce, deep rural region, dotted with informal settlements (informally known as squatter camps).

\subsubsection{Life Design-Based Intervention Research at the GWF}

During 2016, 2017, 2018, and 2019, GWF colleagues and I collaborated on three life design-based projects (see Table 7.1) aimed at demonstrating how life- and career construction (using the $C I P$ and the $M C M$ ) could assist students to choose fields of study, construct themselves and their careers, and eventually design successful lives and make social contributions (Maree, 2019a, 2019b).

The students' positive feedback and exciting progress indicated the success and validity of the intervention strategy (see Table 7.1 below for details), which is also easily replicable in other rural contexts.

\subsubsection{Brief Discussion of the Outcomes of the Intervention (Maree, 2019a, 2019b)}

Some of the trends that emerged from analyzing the data obtained through the projects warrant mention.

First, while the participants' overall career adaptability showed improvement, important differences were noted between the men's and women's pretest and posttest scores in the Career Adapt-Abilities Scale (CAAS; Maree, 2012a). Second, the main finding was that only the women's Curiosity improved significantly (as opposed 
Table 7.1 The life design intervention plan

\begin{tabular}{l|l|l}
\hline Steps & $\begin{array}{l}\text { Intervention objective (Savickas et al., } \\
\text { 2009) }\end{array}$ & $\begin{array}{l}\text { Activities and techniques to achieve } \\
\text { intervention outcomes }\end{array}$ \\
\hline General & $\begin{array}{l}\text { Help participants grow psychologically } \\
\text { and promote their wellbeing }\end{array}$ & $\begin{array}{l}\text { Uncover themes and patterns in } \\
\text { participants' observations, life stories, and } \\
\text { beliefs }\end{array}$ \\
\hline Step 1 & $\begin{array}{l}\text { Establish a satisfactory working } \\
\text { relationship }\end{array}$ & $\begin{array}{l}\text { Conduct group discussions to help } \\
\text { participants get to know each other better. } \\
\text { Complete Part 1 (biographical details) of } \\
\text { the CIP and the MCM }\end{array}$ \\
\hline Step 2 & $\begin{array}{l}\text { Examine participants' (subjective) sense } \\
\text { of self and encourage self-reflection and } \\
\text { reflexivity }\end{array}$ & $\begin{array}{l}\text { Complete Parts 2 and 3 of the CIP. } \\
\text { Participants reflect on their answers }\end{array}$ \\
\hline Step 3 & $\begin{array}{l}\text { Objectify participants' stories and open } \\
\text { up new perspectives on these stories }\end{array}$ & $\begin{array}{l}\text { Participants craft their power, value, or } \\
\text { identity statements and life story titles and } \\
\text { headings. Life stories are (re)constructed } \\
\text { in terms of past and present chapters }\end{array}$ \\
\hline Step 4 6 & $\begin{array}{l}\text { Contextualize challenges or challenging } \\
\text { areas in new stories } \\
\text { Reconfirm participants' capacity to } \\
\text { construct their career identities }\end{array}$ & $\begin{array}{l}\text { Review challenges ("problems") and } \\
\text { consider them as opportunities for growth } \\
\text { Identify and confirm strengths and } \\
\text { problem-solving capacities }\end{array}$ \\
\hline Step 5 & $\begin{array}{l}\text { Construct participants' identities } \\
\text { Jointly design plans to help participants } \\
\text { overcome barriers } \\
\text { Share "new" stories with a } \\
\text { compassionate audience }\end{array}$ & $\begin{array}{l}\text { Revisit power, value, or identity } \\
\text { statements. } \\
\text { Juxtapose painful or hurtful (past) and } \\
\text { hope-filled (future) stories and "faulty" } \\
\text { beliefs and inspiring decisions. } \\
\text { Complete mission and vision statements. } \\
\text { Participants elicit advice from within } \\
\text { themselves by revisiting their favorite } \\
\text { quotations }\end{array}$ \\
\hline $\begin{array}{l}\text { Counselor conducts regular follow-ups and } \\
\text { decides on possible further intervention }\end{array}$ \\
\hline
\end{tabular}

to the improvement in the men's Concern, Control, and Curiosity scores). Third, scrutiny of the women's narratives (qualitative outcomes) confirmed the lowly status of women in this male-dominated, deep rural region where women are generally still expected to be submissive to men, to raise the children, and occupy themselves with household chores. As a result, the female participants seemed more curious about job opportunities, but their depressing circumstances largely precluded their actually converting opportunities into realities. Some of their comments are given below.

"I can only become happy when I leave this place forever" (Sarah, a 22-year-year woman).

"There is no support for my dreams in our township" (Angie, 23 years old).

"My greatest area for development is being unable to stand up for myself" (Pearl, 25 years old). 
Above all, considering factors such as the cost and time to complete projects, the GWF projects (essentially narrative, qualitative, group-based life design interventions in resource-constrained rural environments) are easily replicable in similar contexts. The innovative nature of the approach is lauded and enthusiastically embraced by all concerned. In addition to the positive research outcomes, the projects have already reduced the likelihood of the students discontinuing their participation, dropping out of the projects, ending up on the streets with a bleak future, and swelling the ranks of the unemployed in the region.

Previously (Maree, 2018), I identified some key factors that both individually and collectively promote poverty alleviation, sustainable development, and decent work. First, a keen sense of innovation, goal-setting, planning and implementing rolling plans, flexibility, careful prior planning, willingness to become involved, as well as the capacity to adapt pre-planned schedules, strategies, and interventions as and when needed. Second, accepting the inevitability of change and exhibiting a willingness to embrace a protean change orientation (adapting schedules and making changes when needed). Third, a capacity to renovate old-fashioned ideas and engender new and contextually appropriate ones. Fourth, a sense of actionality (being able and willing to move forward enthusiastically) and the belief that positive developments are about to happen. Fifth, taking the lead and ensuring project sustainability. Sixth, accepting that these kinds of projects almost always occur in uncontrolled conditions (Savickas et al. 2009). Seventh, researchers and practitioners should understand and accept that human behavior can best be comprehended and appreciated only in those contexts where such behavior happens (Brown \& Brooks, 1996). It is therefore essential to abandon predetermined and often biased assumptions about groups of people and how to "help them". Instead, encouraging personal and collective agency and personal authorship should be prioritized. Lastly, unselfishness and a genuine desire to change the lives of vulnerable and marginalized groups of people are prerequisites for the success of any intervention in disadvantaged contexts.

\subsection{Summary}

This chapter covered innovating career counseling to promote social justice (advocacy) and sustainable decent work for all. Sadly, though, despite our best efforts, attempts to implement education, training, and counseling assessment instruments to prepare everyone for a rapidly changing world have been less than successful. In many instances, these efforts may have had unintended adverse effects. For example, it was recently announced that the South Africa education authorities had decided to introduce coding and robotics into schools at Grade 9 level through a subject called "digital learning" to prepare learners for the changed and changing world of work. While this is a laudable idea, only the more affluent schools will be able to afford the state-of-the-art equipment (including computer laboratories) and appoint qualified teachers to teach and train the learners. Most learners in resource-constrained contexts will not have access to this kind of training. Rivett (2019) points out that large 
numbers of properly trained teachers will be needed to execute the plan: "Computers have to be available on the school premises together with the relevant IT infrastructure and internet connectivity" (p. 2). Stringent safety measures will also be needed to prevent equipment from disappearing. The chances of successfully introducing these measures across the continent at present are virtually non-existent. Since "the risk of not being able to attain the skill of coding will be a risk of not attaining a job" (p. 2), these developments will in all likelihood serve only to widen the already huge gap between affluent and indigent people. Rivett righty asks the question: "Will the country end up with another subject that creates 'have and have-nots'?" (p. 2).

On a more positive note: The successful implementation of the career counseling approach advocated in this book in a typical Global South (in this case, African) context is promising and bodes well for the future. I believe that replicating this model across Africa can advance the adaptability and employability of large numbers of impoverished people. Judging by the qualitative feedback of the participants in our own projects, the intervention promoted the welfare of the participants facing extreme hardship and large-scale unemployment. The intervention also reinforced their career resilience and agility, enhanced their career adaptability, promoted their sense of occupational, personal, and self-identity, employability, and improved their chances of finding sustainable decent work (many of them actually succeeded in finding sustainable work ${ }^{1}$ ). The approach therefore holds much promise as a conduit for promoting Goal 8 of the UN Agenda (UN, 2016, p. 1): "Promote sustained, inclusive, and sustainable economic growth, full and productive employment and decent work for all."

In conclusion: The effect of technological advances on the nature of work is felt by many workers across the world currently. Occupational inequality ${ }^{2}$ highlight the ever-growing division in the current workplace. The following is just one example: Remote engagement is bound to become the 'new normal' in work contexts. For various reasons (including the threat posed by the coronavirus pandemic), a large and ever-growing number of people are allowed or even compelled to work remotely. Whereas the majority of more privileged workers are allowed and able to stay (and work from) home, the less privileged still have to travel to the workplace and run the risk of contracting the coronavirus.

I can add also that I agree with Bar-On's (2007) view that conditions in which people are deprived of the opportunity to blossom can hide and perhaps even destroy their self- and career construction. This sad situation compounds the human tragedy stemming from disadvantage, joblessness, and inequality. He rightly asks how many great leaders we have lost/are losing, such as Nelson Mandela, Mother Teresa of Calcutta, Marx, Freud, and Einstein ... people who may have contributed significantly to improving the lives of millions of people. Also, bearing in mind that unemployment is considered a major cause of the Arab Spring, the current situation in Global South countries especially poses a real threat to world peace. I believe that adopting the

\footnotetext{
${ }^{1}$ Colleagues from the GWF regularly update me on the extent to which participants are succeeding in finding sustainable decent work.

${ }^{2}$ See Chap. 7.
} 
twofold Mandela response to counter adversity and its associated challenges will boost our individual and collective efforts to achieve sustainable decent work for all, especially those with economic and other kinds of disadvantage. This response to challenges relates to overcoming major challenges while also taking advantage of the multiple opportunities embedded in change (including the opportunity to make social contributions). This response is well aligned with " $[\mathrm{t}]$ he $21 \mathrm{st}$-century perspective on career counseling [that] moves from the empiricism of objective vocational guiding and the humanism of subjective career developing to the social constructionism of projective life designing" (Savickas, 2015, p. 136).

In Chap. 8, I discuss how the CIP can be used to elicit the life stories of people innovatively and qualitatively.

\section{References}

Bar-On, R. (2007). The relationship between emotional intelligence and giftedness. Gifted Education International, 23, 136-150.

Blustein, D. L., Palladino Schulteiss, D. E., \& Flum, H. (2004). Toward a relational perspective of the psychology of careers and working: A social constructionist analysis. Journal of Vocational Behavior, 6, 423-440.

Brown, D. (2002). Status of theories of career choice and development. In D. Brown, \& Associates (Eds.), Career choice and development (4th ed., pp. 510-515). San Francisco, CA: Jossey-Bass.

Brown, D., \& Brooks, L. (Eds.). (1996). Career choice and development. San Francisco, CA: Jossey-Bass.

Cardoso, P., Silva, J. R., Gonçalves, M. M., \& Duarte, M. E. (2014). Narrative innovation in life design counseling: The case of Ryan. Journal of Vocational Behavior, 85, 276-286. https://doi. org/10.1016/j.jvb.2014.08.001.

Fugate, M., \& Kinicki, A. M. (2008). A dispositional approach to employability: Development of a measure and test of implications for employee reactions to organizational change. Journal of Occupational and Organizational Psychology, 81(3), 503-527.

Guilbert, R., Bernaud, J., Gouvernet, B., \& Rossier, J. (2016). Employability: Review and research prospects. International Journal for Educational and Vocational Guidance, 16(1), 69-89.

International Labor Organization. (2019). World employment and social outlook: Trends 2019. Retrieved from: https://www.ilo.org/global/research/global-reports/weso/2019/lang-en/index. htm.

Maree, J. G. (2010). Brief overview of the advancement of postmodern approaches to career counseling. Journal of Psychology in Africa, 20, 361-369.

Maree, J. G. (2012). Two DVD set: A guide to reflective career counselling-with Prof Maree. Randburg, South Africa: JvR Psychometrics.

Maree, J. G. (2014a). Poverty and life designing. In L. Nota \& J. Rossier (Eds.), Handbook of the life design paradigm: From practice to theory (pp. 233-248). Boston, MA: Hogrefe.

Maree, J. G. (2014b). Creating a sense of hope: The essence of career construction for life designing in a developing country context. In M. Pope, L. Y. Flores, \& J. Rottinghaus (Eds.), The role of values in careers (pp. 213-232). Charlotte, NC: Information Age.

Maree, J. G. (2014c, May). Psychology for all: Examining the merits of a brief, simultaneous, quantitative + qualitative (career) counselling strategy. Keynote address, 5th World Conference on Psychology, Counseling and Guidance, Dubrovnik, Croatia. 
Maree, J. G. (2014d, July). Educing life themes to co-construct life portraits and turn decision into movement. Keynote address (Division 16), 28th International Congress of Applied Psychology. Palais Des Congrès, Paris, France.

Maree, J. G. (2015, September 6). DVD trailer: A guide to reflective career counselling. Retrieved from https://www.youtube.com/watch?v=3Rb8oIJTd6Y.

Maree, J. G. (2018). Using life design counseling for career construction to facilitate sustainable employability and decent work in a developing country context. In V. Cohen-Scali, J. Pouyaud, M. Podgórny, V. Drabik-Podgórny, G. Aisenson, J-L. Bernaud, I. Moumoula., J. Guichard (Eds.), Interventions in career design and education (pp. 195-214). New York, NY: Springer.

Maree, J. G. (2019a, June). Career Development in Africa: Decent work for all: Brief photomontage. Keynote Address at the Annual Career Development Practitioner Congress, Emperors Palace Conference Centre, Kempton Park, South Africa.

Maree, J. G. (2019b). Innovative career construction counselling for a creative adolescent. British Journal of Guidance and Counselling. https://doi.org/10.1080/03069885.2018.1504202.

Maree, J. G. (2019c). Postmodernising career counseling in a deep rural context. In J. G. Maree (Ed.), Handbook of innovative career counseling (pp. 577-596). New York, NY: Springer.

McIlveen, P., Ford, T., \& Dun, K. (2005). A narrative sentence-completion process for systems career assessment. Australian Journal of Career Development, 14, 30-38.

Naidoo, A. V., Pretorius, T. B., \& Nicholas, L. (2017). The emergence of career psychology in South Africa: A socio-historical perspective. In G. B. Stead \& M. B. Watson (Eds.), Career psychology in the South African context (3rd ed., pp. 1-20). Pretoria, South Africa: Van Schaik.

Rivett, U. (2019). Coding in South African schools: What needs to happen to make it work. The Conversation. Retrieved from https://www.moneyweb.co.za/news/tech/coding-in-sa-sch ools-what-needs-to-happen-to-make-it-work/.

Ross, A. (2016). The industries of the future. New York: NY: Simon \& Schuster.

Savickas, M. L. (2011a). Reshaping the story of career counseling. In K. Maree (Ed.), Shaping the story-A guide to facilitate narrative counseling (pp. 1-3). Boston/Rotterdam, The Netherlands: Sense.

Savickas, M. L. (2011b). Career counseling. Washington, DC: American Psychological Association.

Savickas, M. L. (2015). Career counseling paradigms: Guiding, developing, and designing. In P. Hartung, M. Savickas, \& W. Walsh (Eds.), The APA handbook of career intervention (Vol. 1, pp. 129-143). Washington, DC: APA Books.

Savickas, M. L., Nota, L., Rossier, J., \& Dauwalder, J. P., Duarte, M. E., Guichard, J., ... Van Vianen, A. E. M. (2009). Life designing: A paradigm for career construction in the 21st century. Journal of Vocational Behavior, 75, 239-250.

Stevens, G., Duncan, N., \& Sonn, C. (2010). The apartheid archive: Memory, voice and narrative as liberatory praxis. Psychology in Society, 40, 8-28.

United Nations (UN) (2016). Transforming our world: The 2030 Agenda for sustainable development. Retrieved from https://sustainabledevelopment.un.org/post2015/transformingourworld.

United Nations (UN). (2019). Sustainable development goals: 17 goals to transform our world. Retrieved from https://www.un.org/sustainabledevelopment/development-agenda/.

Winnicott, D. W. (1964). The child, the family and the outside world. Cambridge, MA: Perseus. 